\title{
液相における吸着速度に及ぼす 活性炭表面官能基の影響
}

\author{
久代一二*，小田廣和，横川親雄
}

(平成 3 年 1 月 21 日受理)

\section{Effect of Surface Acidic Groups of Activated Carbons on The Adsorption Rate from Aqueous Solutions}

\author{
Kazuji Kushiro*, Hirokazu Oda and Chikao Yokokawa \\ Department of Chemical Engineering, \\ Faculty of Engineering, Kansai University, \\ Suita, Osaka 564, Japan \\ *Present address: Murata Manufacturing Co. Ltd., \\ Youkaichi, Siga 527, Japan
}

The present study deals with elucidating the effect of surface acidic groups of activated carbon on the adsorption rate from aqueous solutions. In order to modify the surface characteristics, a commercial activated carbon was subjected to oxidation reactions with air or aqueous ammonium peroxodisulfate and heat-treatment at $800^{\circ} \mathrm{C}$ under nitrogen atmosphere. The samples thus obtained were determined the adsorption rates of benzoic acid and phenol from aqueous solutions. The amounts of equiliblium adsorbed of phenol and benzoic acid decrease with increasing the acidities of activated carbon surface. It was found that adsorption rate is retarded considerably by the acidities of activated carbons.

KEYWORDS: Activated carbon, Adsorption rate, Surface acidic groups

\section{1. 緒言}

活性炭は多孔性構造の発達した炭素材料であり, 吸着 剤として各方面で利用されている。吸着現象に関しては 英大な研究報告の蓄積があるが ${ }^{11,2)}$, 活性炭についてみると, その実用性能が比表面積, 細孔容積および細孔径分布と いった物理的性質に大きく依存するので, 活性炭の研究 では，比表面積の大きいあのを高収率で製造することや 細孔径分布を制御するてとなどに努力が注がれてきた ${ }^{3)-8) ~}$ ところで, 吸着現象が吸着質と吸着媒との間に働く

関西大学工学部化学工学教室： 5564 吹田市山手町

* 現在, 村田製作所 : 527 八日市市東沖野 4-4-1 van der Waals力に支配されることに違いはなく, 活 性炭表面の化学的特性とその吸着特性との関係が提起さ れたのは比較的最近のことである。液相からの吸着にあ っては溶媒一溶質一吸着媒の間に働く引力と斥力とのバ ランスが系の吸着特性を決定するとしてTraube の法則 が認めら机ていだ9)。すなわち, 1970年代に入って, 力 一ボンブラック表面の化学的性質が論じられるようにな ったが ${ }^{10),}{ }^{11}$, 著者ら ${ }^{12)-14)}$ はこれに注目して, 化学的処 理によって表面の酸性基量の異なる活性炭を作成し, 比 表面積ならびに細孔径分布などの物理的性状に大きな差 異がなくても, 表面酸性基量に差異があると各種の吸着 質に対する飽和吸着量ならび吸着選択性に著しい差異が 生じるととを報告した。乙れらの報告は平衡論に立脚す 
Table 1 Characteristics of the activated carbons used.

\begin{tabular}{l|ccc}
\hline $\begin{array}{c}\text { Activated } \\
\text { carbons }\end{array}$ & $\begin{array}{c}\text { Specific } \\
\text { surface area } \\
{\left[\mathrm{m}^{2} / \mathrm{g}\right]}\end{array}$ & $\begin{array}{c}\text { Pore } \\
\text { volume } \\
{[\mathrm{ml} / \mathrm{g}]}\end{array}$ & $\begin{array}{c}\text { Yield } \\
{[\%]}\end{array}$ \\
\hline Original & 990 & 0.39 & - \\
H-T & 1010 & 0.38 & 98 \\
A-O & 1030 & 0.40 & 99 \\
W-O & 890 & 0.31 & 110 \\
(W-O)-(H-T) & 980 & - & $84^{\mathrm{c})}$ \\
\hline
\end{tabular}

a) BET procedure with nitrogen

b) Based on the desorption isotherm for water vapour and hence the pores whose diameter is less than $60 \AA$ c) Based on W-O

るあのであるが，本研究は吸着速度の面からての問題を 考察しようとするものである。すなわち，市販の活性炭 を熱処理, 空気酸化および液相酸化の 3 つの方法で表面 を処理して酸性基量の異なる活性炭を調整し，乙れらの 活性炭による水溶液からの安息香酸掞よびフェノールの 吸着速度を測定して, 相互の関係を比較検討した。

\section{2. 実験方法}

\section{1 試料活性炭}

試料活性炭は, チャコール活性炭（和光純薬 KK）を 10 〜32 Tyler meshに粒度調整したあのであり, この活性 炭を以下のような方法で表面の処理を行なった。

（a） $800^{\circ} \mathrm{C}$ 熱処理：窒素雾团気中で $800^{\circ} \mathrm{C}$ 亿昇温

( $5{ }^{\circ} \mathrm{C} / \mathrm{min}$.)し, 乙の温度に $1 \mathrm{hr}$ 保った後に室温まで冷 却した（以下 $\mathrm{H}-\mathrm{T}$ と略記する）。

(b) 空気酸化: 湿潤空気の気流中 $(1 \mathrm{l} / \mathrm{min}$. $)$ で $350^{\circ} \mathrm{C}$ まで昇温して $5 \mathrm{hr}$ 保持し，そのまま室温まで冷却した (以下A - $\mathrm{O}$ と略記する)。

(c) 液相酸化: 活性炭約 $100 \mathrm{~g}$ を $1 \mathrm{~mol} / \ell$ の $\left(\mathrm{NH}_{4}\right)_{2}$ $\mathrm{S}_{2} \mathrm{O}_{8}$ 水溶液 $3 \ell$ 中に入れて 2 昼夜放置した後, 万別し, 水洗, 乾燥した（以下 $\mathrm{W}-\mathrm{O}$ 之略記する）。

(d) 液相酸化活性炭の再熱処理：W-O を再び上述の(a) の方法で熱処理した (以下 $(\mathrm{W}-\mathrm{O})-(\mathrm{H}-\mathrm{T})$ と略記 する)。

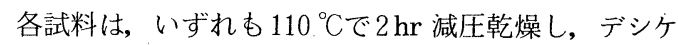
ーター中で保存した。

\section{2 比表面積の測定法}

定容型吸着装置（BET装置）を用いた。試料約 0.2 $\mathrm{g}$ を種々の相対圧（ $0.05 \sim 0.35$ 範囲で 4 点）に扔いて 窒素ガスの平衡吸着量を測定し, 得られた吸着等温線を
BET解析して比表面積を求めた。

\section{3 細孔容積および細孔径分布の測定法}

前報に準じて ${ }^{6}$ 試料約 $0.5 \mathrm{~g}$ を精秤し,ての屯のに50 ${ }^{\circ} \mathrm{C}$, 相対湿度 $100 \%$ の下で平衡に達するまで水蒸気を吸 着させた (平衡に達するまで一週間)。乙の試料を各種 濃度の硫酸水溶液（ $65 ， 55 ， 45 ， 35 ， 25$ および15\%) の $50 \mathrm{~m} \ell$ を入れガラス容器中に密封し, 恒温器内で50 ${ }^{\circ} \mathrm{C}$ に保った。試料重量の経時変化を追跡し, 各飽和水蒸 気下に打ける活性炭試料の飽和水分量を求めて脱着等温 線を作成した。得られた脱着等温線より Kelvin 式で細 孔径分布を求めた。

\section{4 酸性基当量の測定法}

H. P. Boehm ら ${ }^{10)}$ がカーボンブラックに適応した方法 に準拠した。すなわち, 活性炭試料 $0.5 \mathrm{~g}$ を精秤し, てれ に50 m $\ell$ の各種塩基性水溶液 $\left(\mathrm{NaHCO}_{3}, \mathrm{Na}_{2} \mathrm{CO}_{3}\right.$, 打 よび $\mathrm{NaOH}$ の各 $\mathrm{N} / 20$ 溶液）をそれぞれ加えて室温で24 $\mathrm{hr}$ 静置した。反応後, 万過し, てのろ夜をメチルオレン ジを指示薬としてN/20-HClで逆滴定した。

\section{5 平衡吸着量の測定法}

$\mathrm{N} / 100$ の吸着質（安息香酸あるいはフェノール）の水 溶液 $100 \mathrm{~m}$ l亿試料活性炭 $200 \pm 1 \mathrm{mg}$ を加え, $20^{\circ} \mathrm{C}$ で一 昼夜静置した。なお, 安息香酸の濃度はてれより $25 \mathrm{~m} \ell$ 採取し中和滴定法によって求めた。一方, フェノールの 濃度は分光光度計で $270 \mathrm{~nm}$ の吸光度を測定し, あらかじ め作成した検量線から求めた。

\section{6 吸着速度の測定法}

吸着速度を $20^{\circ} \mathrm{C}$ なびに $35^{\circ} \mathrm{C} に$ 扔いて測定した。すな わち, 10個の共栓付きエレンマイヤーフラスコを用意し, それぞれに $\mathrm{N} / 100$ の吸着質の水溶液 $100 \mathrm{~m} \ell$ と試料活性 炭 $200 \pm 1 \mathrm{mg}$ を加えて恒温槽内に置いた。それぞれのフ ラスコから 5 分毎に溶液を採取し, 前述の（2.5) の方 法で吸着量を求めた。

\section{3. 実験結果および考察}

\section{1 各種活性炭の性状}

\subsection{1 比表面積および細孔容積}

原試料活性炭ならびに処理を施した各種活性炭の比表 面積之細孔容積を Table 1 亿示した。原試料活性炭の比 表面積は $990 \mathrm{~m}^{2} / \mathrm{g}$ 程度であり, $\mathrm{H}$-TやA-Oによって それぞれ $1010 \mathrm{~m}^{2} / \mathrm{g}$ および $1030 \mathrm{~m}^{2} / \mathrm{g}$ とやや大きくなる がその変化はさほど大きなあのではない。これに対し, $\mathrm{W}-\mathrm{O}$ の比表面積は $890 \mathrm{~m}^{2} / \mathrm{g}$ となって, 乙の処理によっ て10\%程度小さくなる。な抢, 収率は $\mathrm{H}-\mathrm{T}$ および $\mathrm{A}$ Oで $100 \%$ をやや下まわる゙，W-Oでは $110 \%$ となり， 孔隙壁に多量の表面酸性基が導入されたととを示唆する あのである。 


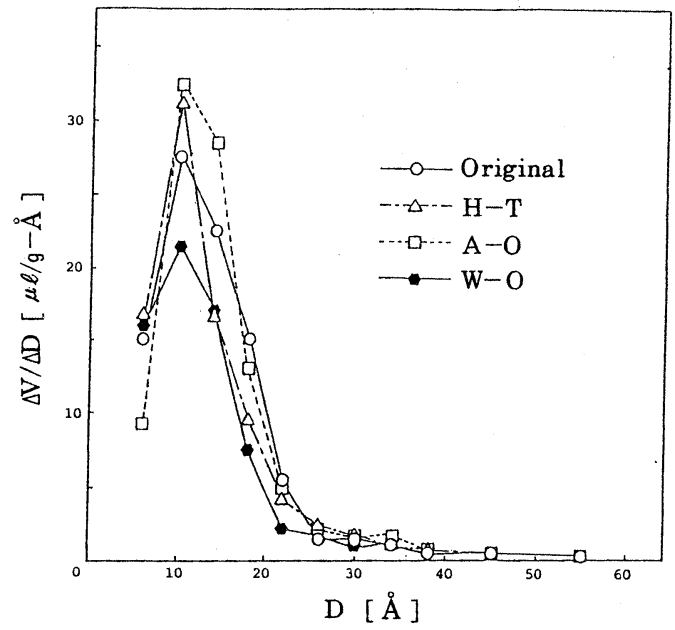

Fig. 1 Pore-size distribution of the activated carbons.

\subsection{2 細孔径分布曲線}

Fig. 1に 4 種の活性炭の細孔径分布を示した。いずれ の活性炭も直径 $10 \AA$ 付近に発達したピークが認められる。 $\mathrm{A}$ - $\mathrm{O}$ によって若干の変化は認められるが，4種の活性 炭の間に細孔径分布に関しては著しい差異はないものと 考えられる。

\section{2 表面官能基量の変化}

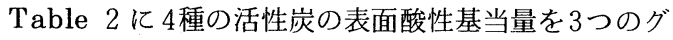
ループ*分別して表わした。原試料活性炭の全酸性基当 量は $0.17 \mathrm{meq} / \mathrm{g}$ であって, そのほとんどはフェノール性 水酸基であり, $\mathrm{H}$ - Tによってそれが分解されて 0.09 $\mathrm{meq} / \mathrm{g}$ に減少する。一方, A - O 亿よって表面酸性基 量は, 原試料活性炭に比べてカルボキシル基で約10倍, 全量で約 2.5 倍になる。さらに, W-O ではきわめて多 量のカルボキシル基が導入され, 全酸性基量は約20倍に なる。

\section{3 各種吸着質の平衡吸着量}

各種活性炭に対するフェノールと安息香酸の平衡吸着 量をTable 3 に示した。いずれの活性炭に沶いても安息 香酸の吸着量がフェノールの吸着量より大である。乙れ は前報6) ですでに述べた様に, 両吸着質の水に対する溶 解度の差に起因するあのである。すなわち, $20^{\circ} \mathrm{C} に お け$ る安息香酸の溶解度は $2.9 \mathrm{~g} / \ell$ であり,フェノールのそれ

${ }^{*}$ H. P. Boehm らに従うと, $\mathrm{NaHCO}_{3}, \mathrm{Na}_{2} \mathrm{CO}_{3}$ およ び $\mathrm{NaOH}$ とのみそれぞれ反応する酸性基は各々カルボ キシル, ラクトンとして存在するカルボキシル基, そ してフェノール性水酸基であるとしている。
Table 2 Acidic groups of the adsorbents.

\begin{tabular}{l|rcc|rcr}
\hline \multirow{2}{*}{ Treatments } & \multicolumn{3}{|c|}{$\begin{array}{c}\text { Acidity } \\
{[\mathrm{meq} / \mathrm{g}]}\end{array}$} & \multicolumn{3}{c}{$\begin{array}{c}\text { Surface group x } \\
{\left[\mathrm{meq} / \mathrm{m}^{2}\right]}\end{array}$} \\
\cline { 2 - 7 } & $\mathrm{NaHCO}_{3}$ & $\mathrm{Na}_{2} \mathrm{CO}_{3}$ & $\mathrm{NaOH}$ & \multicolumn{1}{c}{$\mathrm{I}$} & $\mathrm{II}$ & III \\
\hline Original & 0.01 & 0.02 & 0.17 & 0.1 & 0.1 & 1.5 \\
H-T & -0.03 & 0.01 & 0.09 & 0.0 & 0.1 & 0.8 \\
A-O & 0.09 & 0.23 & 0.43 & 0.9 & 1.4 & 1.9 \\
W-O & 1.74 & 2.07 & 3.13 & 21.4 & 4.1 & 13.1 \\
(W-O)-(H-T) & -0.01 & 0.00 & 0.01 & -0.1 & 0.0 & 0.1 \\
\hline
\end{tabular}

I: Strong carboxyl group. II: Weak carboxyl group. III: Phenolic hydroxyl group.

Table 3 Amounts adsorbed at equilibrium state.

\begin{tabular}{l|l|c|c}
\hline \multirow{2}{*}{ Adsorbates } & \multirow{2}{*}{ Carbons } & \multicolumn{2}{|c}{ Amounts adsorbed [m-mol/g] } \\
\cline { 3 - 4 } Phenol & Original & 2.68 & $35^{\circ} \mathrm{C}$ \\
\hline \multirow{5}{*}{ Benzoic acid } & H-T & 2.81 & 2.61 \\
& A-O & 2.39 & 2.33 \\
& W-O & 0.85 & 0.88 \\
& A-O & 2.34 & - \\
\hline \multirow{5}{*}{} & W-O)-(H-T) & 3.08 & 3.08 \\
& Original & 3.21 & 3.21 \\
& W-O & 3.03 & 3.03 \\
& (W-O)-(H-T) & 2.71 & 1.27 \\
\hline
\end{tabular}

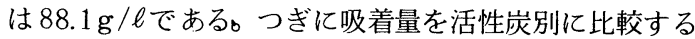
と,フェノールおよび安息香酸ともに $\mathrm{H}-\mathrm{T}$ では増大し, $\mathrm{A}$ - $\mathrm{O}$ 扰よび $\mathrm{W}$ - $\mathrm{O}$ では逆に減少した。乙の理由を特定 することは困難であるが，以下のように考えることがで きると思われる。すなわち， $\mathrm{H}-\mathrm{T}$ 亿よると，酸性基当 量数の減少にともなってBET 比表面積の増大と同じく 平衡吸着量の增大が認められるのであるから, 酸性基の 除去によって新しく表面が生成し，それに伴って吸着席 の数あ多くなるあのと思われる。乙れに対し，A-Oに よって比表面積の増大がみられるととから新しい表面の 生成があると考えられるが，表面の吸着席の一部は生成 した酸性基によって占められるため飽和吸着量は低下す るあのと考えられる。一方，W-OKあってはその酸化 反応の程度が大であって細孔の一部が破壊されて比表面 積の低下が起とり，な扔かつ吸着席の多くが酸性基によ って占められるので飽和吸着量が著しく小さくなったす のと考えられる。

吸着は発熱を伴う現象であるから, 温度が高くなると 吸着量は減少するはずである。しかし, 本実験に招いて, $20^{\circ} \mathrm{C}$ と $35^{\circ} \mathrm{C}$ では平衡吸着量にほとんど差は認められなか った。 


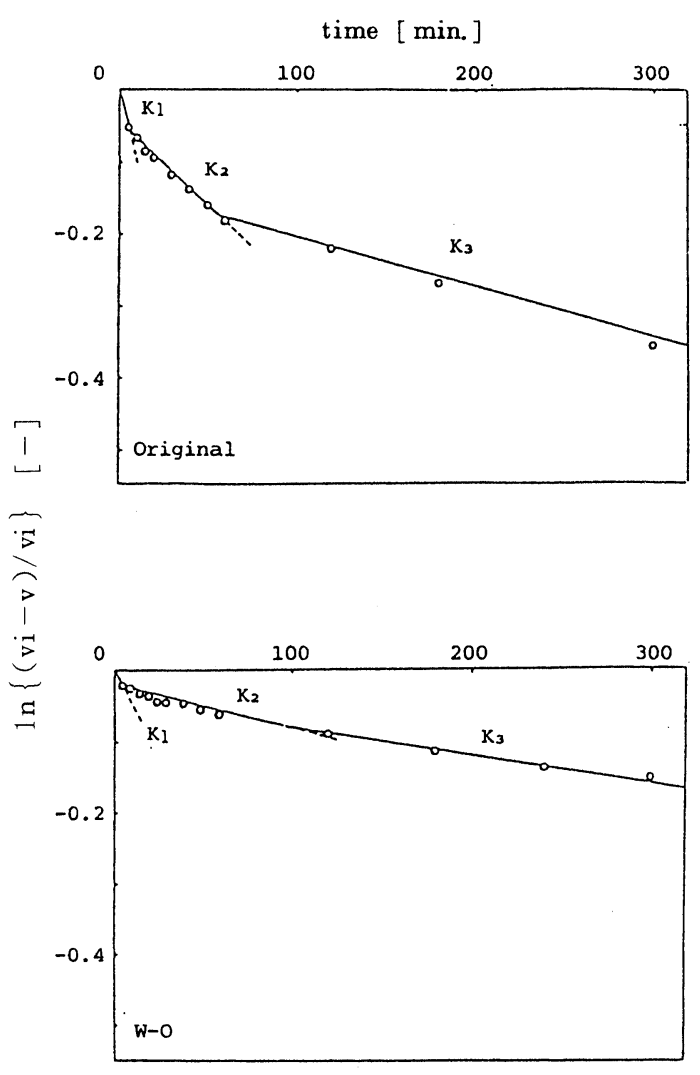

Fig. 2 Relationships between time and $\ln$ $[(\mathrm{Vi}-\mathrm{V}) / \mathrm{Vi}]$ on the activated carbons for phenol at $20^{\circ} \mathrm{C}$.

Vi: Initial concentration $\left[10^{-2} \mathrm{~mol} / \ell\right]$

$\mathrm{V}$ : Amounts of adsorption at any time $\left[10^{-2} \mathrm{~mol} / \mathrm{l}\right]$

\section{4 吸着速度}

原試料活性炭打よび $\mathrm{W}-\mathrm{O}$ 活性炭に対する両吸着質の 吸着量の経時変化を一次速度式に適用して整理したとて ろ，すべての系に対してFig. 2をよび3に例示したよう な関係が得られた。すなわち, 初期段階（5 分程度）に 扔ける吸着速度はきわめて大きいために原点を通らない 直線となるが，吸着は打打む称了つの異なったプロセ スにより進行するあのと考えてよいと思われる。てれら の具体的な機構を特定することはできないが, 吸着速度 の大小をてれらの速度定数を用いて比較することは可能 であると思われる。こてで，便宜的に初期段階に打ける 一次速度定数を $\mathrm{K}_{1}$, 次の段階のそれを $\mathrm{K}_{2}, \mathrm{~K}_{3}$ として Table 4 亿示した。 $\mathrm{K}_{1}$ の測定精度は十分でなく,一方, $\mathrm{K}_{3}$ は吸着後期であるから $\mathrm{K}_{2}$ を対象として考察するの が合理的であると思われる。先ず $K_{2}$ の温度依存性を見

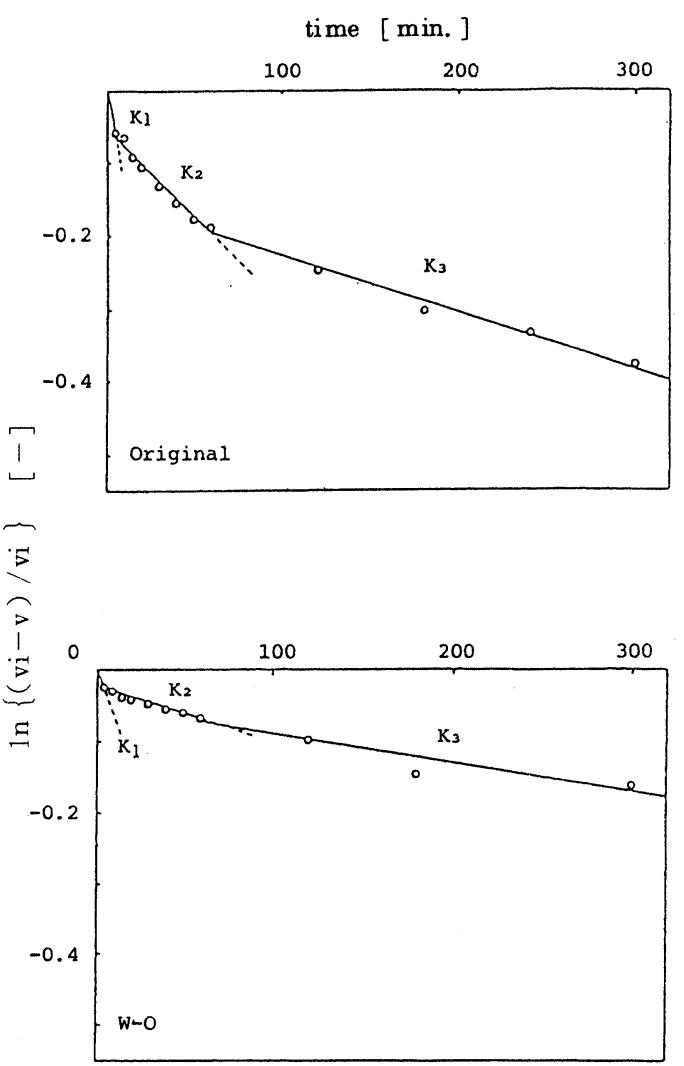

Fig. 3 Relationships between time and $\ln$ $[(\mathrm{Vi}-\mathrm{V}) / \mathrm{Vi}]$ on the activated carbons for benzoic acid at $20^{\circ} \mathrm{C}$.

Vi: Initial concentration $\left[10^{-2} \mathrm{~mol} / \mathrm{l}\right]$

$\mathrm{V}$ : Amounts of adsorption at any time $\left[10^{-2} \mathrm{~mol} / \mathrm{l}\right]$

ると, $20^{\circ} \mathrm{C}$ と $35^{\circ} \mathrm{C}$ 間の活性化エネルギーは約 $5 \mathrm{kcal} /$ $\mathrm{mol}$ であって, 吸着は拡散律速である。ついで各試料間 の $\mathrm{K}_{2}$ を比較すると酸性基当量の大きい活性炭で $\mathrm{K}$ が小 さくなっているてとが示されている。すなわち, 酸性基 の存在は吸着速度を小さくする効果を持つと考えられる。

ところで, 本実験は吸着質水溶液の濃度ならびに絶対 量を一定とし, 吸着媒すなわち活性炭量屯一定として行 なわれた。一方で飽和吸着量, すなわち吸着席数は試料 活性炭の種類によって異なるのであるから，吸着速度の 比較は単位吸着席当たりの值で行なうのが合理的である と考えられる。乙のような観点加ら表 4 亿は各系に対し て見掛けの一次速度定数 $\mathrm{K}$ を吸着席当たりに換算した比 速度定数 $\mathrm{K}^{\prime}$ を伴せて示した。乙てでも $\mathrm{K}_{2}$ 'を対象とし て議論するのが妥当であると考えられる。 $\mathrm{K}_{2}$ ’を活性炭 別に比較すると， $\mathrm{K}_{2}$ について示したように表面酸性基 
Table 4 The rate constant and the specific rate contant.

\begin{tabular}{|c|c|c|c|c|c|c|c|c|c|c|c|c|c|c|c|}
\hline \multirow[t]{2}{*}{ Adsorbates } & \multirow[t]{2}{*}{ Carbons } & \multicolumn{2}{|c|}{$\begin{array}{c}\mathrm{K}_{1} \\
10^{-3}\left[\mathrm{~min}^{-1}\right]\end{array}$} & \multicolumn{2}{|c|}{$\begin{array}{c}\mathrm{K}_{2} \\
10^{-3}\left[\mathrm{~min}^{-1}\right]\end{array}$} & \multicolumn{2}{|c|}{$\begin{array}{c}\mathrm{K}_{3} \\
10^{-3}\left[\mathrm{~min}^{-1}\right]\end{array}$} & \multicolumn{2}{|c|}{$\begin{array}{c}\mathrm{K}_{1}{ }^{\prime a)} \\
10^{-3}\left[\mathrm{~min}^{-1}\right]\end{array}$} & \multicolumn{2}{|c|}{$\begin{array}{c}\mathrm{K}_{2}{ }^{\mathrm{a})} \\
10^{-3}\left[\mathrm{~min}^{-1}\right]\end{array}$} & \multicolumn{2}{|c|}{$\begin{array}{c}\mathrm{K}_{3}{ }^{\prime a)} \\
10^{-3}\left[\mathrm{~min}^{-1}\right]\end{array}$} & \multicolumn{2}{|c|}{$\begin{array}{c}\begin{array}{c}\text { Relative } \\
\text { coverage b) } \\
{[\%]}\end{array} \\
\end{array}$} \\
\hline & & $20^{\circ} \mathrm{C}$ & $35^{\circ} \mathrm{C}$ & $20^{\circ} \mathrm{C}$ & $35^{\circ} \mathrm{C}$ & $20^{\circ} \mathrm{C}$ & $35^{\circ} \mathrm{C}$ & $20^{\circ} \mathrm{C}$ & $35^{\circ} \mathrm{C}$ & $20^{\circ} \mathrm{C}$ & $35^{\circ} \mathrm{C}$ & $20^{\circ} \mathrm{C}$ & $35^{\circ} \mathrm{C}$ & $20^{\circ} \mathrm{C}$ & $35^{\circ} \mathrm{C}$ \\
\hline \multirow{5}{*}{ Phenol } & & 11.0 & 18.0 & 2.3 & 3.5 & 0.7 & 0.8 & $11: 0$ & 18.0 & 2.3 & 3.5 & 0.7 & 0.8 & 29 & 41 \\
\hline & & 11.0 & 15.6 & 2.7 & 3.8 & 0.8 & 0.9 & 10.5 & 14.4 & 2.6 & 3.5 & 0.8 & 0.8 & 28 & 44 \\
\hline & $\mathrm{A}$ & 8.9 & 18.0 & 1.8 & 3.4 & 0.6 & 0.6 & 10.0 & 20.2 & 2.0 & 3.8 & 0.7 & 0.7 & 30 & 44 \\
\hline & 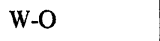 & 4.3 & 5.2 & 0.5 & 1.1 & 0.3 & 0.4 & 13.6 & 15.4 & 1.6 & 3.3 & 0.9 & 1.2 & 25 & 45 \\
\hline & 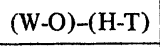 & 13.2 & - & 2.1 & - & 0.7 & - & 15.1 & - & 2.4 & - & 0.8 & - & 36 & - \\
\hline \multirow{5}{*}{$\begin{array}{l}\text { Benzoic } \\
\text { acid }\end{array}$} & & 11.9 & 14.4 & 2.4 & 3.1 & 1 & 1.2 & 11.9 & 14.4 & 2. & 3.1 & 1. & 1.2 & 2 & 35 \\
\hline & H-T & 10.3 & 18.4 & 2.6 & 3.2 & 0.8 & 1.0 & 9.9 & 17.7 & 2.5 & 3.1 & 0.8 & 1.0 & 27 & 37 \\
\hline & $\mathrm{A}-\mathrm{O}$ & 10.1 & 14.8 & 2.4 & 3.1 & 1.0 & 1.2 & 10.3 & 15.0 & 2.4 & 3.2 & 1.0 & 1.2 & 20 & 36 \\
\hline & W-O & 4.9 & 6.0 & 0.7 & 1.2 & 0.3 & 0.6 & 12.3 & 14.6 & 1.8 & 2.9 & 0.8 & 1.5 & 25 & 37 \\
\hline & $(\mathrm{W}-\mathrm{O})-(\mathrm{H}-\mathrm{T})$ & 16.8 & - & 2.1 & - & 1.4 & - & 16.6 & - & 2.1 & 一 & 1.4 & - & 33 & - \\
\hline
\end{tabular}

a) $\mathrm{K} \times \frac{\mathrm{Oe}}{\mathrm{Me}}$

Oe: Amounts adsorbed on the original carbon at the equilibrium state

b) $\mathrm{AK} \quad \mathrm{AK}$ : Amounts adsorbed at the end of the process controlled by $\mathrm{K}_{2}$

Ae: Amounts adsorbed at the equilibrium state

が吸着速度を小さくするてとがわかる。これらのことを つぎに示すような吸着席モデルで考えてみる。いま表面

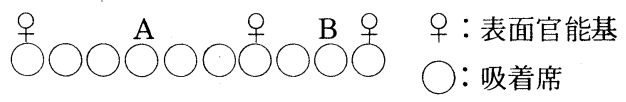

に吸着サイト A, B があるとする。表面官能基に隣接し ているサイト Bとてれより離れているサイトAを比較す ると, サイト $\mathrm{B}$ は官能基の影響を直接受けて吸着能力を 十分に発揮するてとができないと考えられる。したがっ て $\mathrm{H}$ - Tで吸着速度は大きくなり, $\mathrm{A}-\mathrm{O}$ および $\mathrm{W}-\mathrm{O}$ で吸着速度は小さくなるが，乙の影響は多量に表面酸性 基を生成した $\mathrm{W}$ - Oに拉いて顕著に現われた。とてろで， 活性炭を熱処理するとその表面官能基が分解することは すでに知られている ${ }^{13)}$ 。そこで $\mathrm{W}-\mathrm{O}$ に熱処理 $\left(800^{\circ} \mathrm{C}\right.$, $1 \mathrm{hr})$ を施した。乙の $(\mathrm{W}-\mathrm{O})-(\mathrm{H}-\mathrm{T})$ の表面酸性 基量は $0.01 \mathrm{meq} / \mathrm{g}$, 比表面積は $980 \mathrm{~m}^{2} / \mathrm{g}$ となり, 原試 料活性炭の性状と大差がみられなくなった。この試料活 性炭に対する両吸着速度を測定したところ, Table 4 に 示したように再び吸着速度が大きくなることが確かめら れた。このことは表面酸性基が吸着速度を著しく小さく する効果を持つととが実証されたあのと考えられる。

一方， $35^{\circ} \mathrm{C}$ に打ける速度定数は，いずれの吸着質に対 しても大きくなり，表面酸性の影響は相対的に小さくな って各活性炭の間に大きな差が認められなくなった。

\section{4. 結言}

表面官能基量の異なる活性炭を用いて水溶液からのフ ェノールおよび安息香酸の吸着速度を測定した。活性炭 の表面酸性基当量が大きいほど水溶液からのフェノ一ル あるいは安息香酸の平衡吸着量が小さくなることは前 報 ${ }^{6)}$ に述べたと打りであるが, 吸着速度も酸性基当量に 支配され, 酸性基当量が大になると小さくなることが示 された。

\section{引用 文 献}

1) J.J. Kipling, "Adsorption from solutions of non-electrolytes", Academic Press, London (1965)

2) J.S. Mattoson, H.B. Mark. Jr., "Activated Carbon", Marcel Dekker Inc., New York (1971)

3) 北川 浩, 日化 74, 1383 (1971)

4) ibid. 75, 1444 (1972)

5) H. Marsh and D. Crawford, Carbon 20, 419 (1982)

6) ibid 22, 603 (1984)

7) F. Rodriguez-Reinoso, J. De. LopezGonzalez and C. Berenguer, Carbon 20, 513 (1982)

8) T. Yamaguchi, Fuel 59, 445 (1980)

9) J.S. Mattson, H.B. Mark. Jr., "Activated 
Carbon" Marcel Dekker Inc., P. 167 (1971) New York

10) H.P. Boehm, Angew Chem. 78, 617 (1966)

11) V.A. Garten, D.E. Weiss and J.B. Willis, Austral. J. Chem. 10, 295 (1957)

12) H. Oda, M. Kishida and C. Yokokawa,
Carbon 19, 243 (1981)

13) H. Oda and C. Yokokawa, ibid. 21, 303 (1983)

14) H. Oda and C. Yokokawa, ibid. 21, 485 (1983)

\title{
日本学術会議第 5 部報告
}

\section{エ学教育に関する諸問題と対応一特に産業社会の視点からー (要約)}

\begin{abstract}
$\left(\begin{array}{l}\text { 平成 } 3 \text { 年 } 3 \text { 月 } 25 \text { 日 } \\ \text { 日本学術会議第 } 5 \text { 部 }\end{array}\right)$
近年の科学の進歩に基づく技術革新は, 産業構造々社 会構造の変革をもたらし，乙の波は更に幅広く奥深い技 術の進展を伴って産業社会に本質的なインパクトを与え つつある。乙れに対応して，わが国の産業界では，新技 術の創成に向けて研究設備の充実之人材の確保に積極的 な投資がなされている。一方, 工学系大学であ, 新時代 の工学教育の在り方が模索されてはいるが，文教予算の 伸びの遅れ之政府の研究投資の低さのため, 施設や設備 の充実は進まず, 教育・研究の環境は極めて劣悪な状態 にある。

工学系大学では, 学問や技術の深化に伴う学部の巨大 化や専門教育刀細分化に由来して,「あのをつくる」立場 からの工学の統合的視野の希薄化が危惧され, また, 高 度の技術社会に対応して「人工系科学」を含めた総合的 視野の必要性が叫ばれるなど, 工学系技術者育成の質と 量の問題が顕在化している。

技術革新による時代の転換期にあたって，天然資源に そしく産業の発展に国力の基盤を置くわが国の立場を省 み, また将来の工学系技術者の質之量の需給の不均衡が 憂慮される現状から，工学教育の在り方を産業社会への 貢献という立場に視点をあてて検討するてとが緊要であ る。欧米諸国も近年, 国力の基盤はその国の技術競争力 にあるとの認識を新たにし，てれを支える人材育成のた めに工学教育の在り方について新しい政策の展開を図り つつある。

大学等に打ける工学教育の諸問題に関しては, 文部省, 通商産業省, 科学技術庁, 経済団体連合会等で, それぞ れ審議が進められ，多くの指摘がなされている。本報告 は, てれらとは異なる立場すなわち大学と産業界との接

点に焦点を絞り, 人材需給のインバランス, 工学教育の 総合化，技術者の継続教育，国際交流基盤としての学部 - 学科の評価の問題, 大学行政・組織の弾力的運営, 政 府の対応，などを中心々審議検討したもので, 工学教育 の在り方を網羅的潘議した結果ではない。しかし工学 系教育が, この变革期に際して, 新たな伝統を築くべく 踏み出すととを強く望む結果となった。

産業界之学界は「工学系技術者の育成にかかわる工学 教育は, わが国にとってその将来を左右する基本的課題 である」との認識のあとで, 下記事項の状況把握に努め, その対応策を協議する必要がある。

(1) 産業界の人材需給問題の把握と長期予想

(2) 社会的要請・社会情勢の進展への大学の対応

(3) 大学組織 (学部・大学院の構成), 学生定員, カリ キュラム等への産業界からの要請

(4) 産・官・学界の協力による工学系技術者の継続教 育体制の確立

(5) 工学教育にかかわる大学の環境整備及びそ机にか かわる税制その他の制度の整備

(6) 国際交流に対処し得る学部 (学科)・大学院 (専攻) の評価・認定体制，等である。

これらの事項の具体的状況把握ならびに対応策の協議 にあたり，工学教育が産業社会の拠り所であり国の基本 政策であるとの認識のもとに，まず産・学両界トップメ ンバーによって構成される「工学教育トップフォーラム」 の設置が望まれることを，本報告は結論としている。 [附記 ] 経団連関係首脳, 日本工学了カデミー首脳, 文 部省関係局長・課長, および大学関係者により, 本目的 に沿った準備会合が平成 3 年 1 月にすでに開かれている。
\end{abstract}

